\title{
Pensar a obra rulfiana: ficção literária latino-americana, História do México e Modernidade na obra de Juan Rulfo ${ }^{1}$
}

\author{
Marcos Vinícius Gontijo ${ }^{2}$
}

Resumo: O presente artigo é resultado parcial da investigação sobre a obra do escritor mexicano Juan Rulfo (1917-1986) no qual estão expostos os caminhos que a pesquisa de mestrado sobre o escritor e aspectos de sua obra têm trilhado até o momento. Para tanto, sustenta como problema fundamental o processo de modernização mexicano e o período pós-revolucionário, ambos relacionados estritamente à narrativa de Rulfo. A análise delineia-se em torno das características que sustentam o enredo do romance Pedro Páramo (1955), tais como: a temporalidade, a ordem singular da memória, a ficcionalização da oralidade, as alegorias criadas, e o trato com as variadas dimensões da língua e do espanhol mexicano. Ainda nos são caros os conceitos de Arquivo e Mito, utilizados por Roberto González Echevaría na obra Mito y archivo; o conceito de transculturação, mobilizado por Ángel Rama em Transculturación narrativa en América Latina; bem como o diálogo contínuo com a crítica e a teoria literária a partir de autores e autoras como Rolland Barthes, Gilles Deleuze e Irlemar Chiampi. Por fim, visto que a pesquisa tem como fonte histórica a ficção literária, embasamos nossa concepção sobre as interações entre ficção, imaginário e real no trabalho de Wolfgang Iser.

Palavras-chave: Revolução Mexicana; Modernização; Modernidade; História da Literatura; Juan Rulfo.

1 A escrita do presente artigo contou com sugestões e orientação da profa. dra. Adriane Aparecida Vidal Costa durante a graduação do autor na Universidade Federal de Minas Gerais (UFMG). Momento em que se iniciaram seu interesse pela literatura latino-americana, em especial a obra de Juan Rulfo, e a pesquisa - agora continuada durante o mestrado desde o primeiro semestre de 2018, sob orientação do prof. dr. Mateus Fávaro Reis na Universidade Federal de Ouro Preto (UFOP).

${ }^{2}$ Mestrando do programa de pós-graduação em História da Universidade Federal de Ouro Preto (UFOP), Brasil, onde o projeto de pesquisa, Juan Rulfo, um intérprete da Revolução: campo, cidade e modernização no México pós-revolucionário (1945-1979) teve início em abril de 2018, com financiamento da CAPES. E-mail: agourovirtual@gmail.com

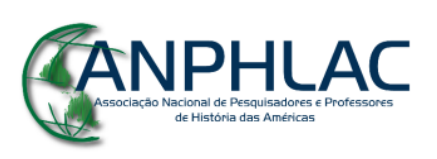

Revista Eletrônica da ANPHLAC, ISSN 1679-1061, №. 25, p. 222-251, Jul./Dez., 2018.

http://revista.anphlac.org.br 


\title{
Thinking the Juan Rulfo's work: Latin-american's literary fiction, History of Mexico and Modernity
}

\begin{abstract}
This article is a partial result of an investigation about the Mexican writer Juan Rulfo's (1917-1986) work. Here, the paths of the mastered degree'sresearch are exposed, bringing the aspects about the writer and his work. Thereunto, it holds as its fundamental problem the Mexican modernization process and the pos-revolucionary period, both related to the Rulfo's narrative. The analysis worries itself about the lines that support the novel's plot Pedro Páramo (1955), it's the temporality, the memory order, the oral ficcionalization, the allegories invented, and the trait with the various dimensions of the language and the Mexican Spanish. Also, is important to us the concepts of Archive and myth, used by Roberto González Echevaría in the book Mito y Archivo; the concept of transculturation, engaged by Ángel Rama in Transculturación narrative en América Latina; and the continuous dialog with the critics and the literary theory, from authors such as Rolland Barthes, Gilles Deleuze and Irlemar Chiampi. Although, looking at the historic document as a literary fiction that the research has, the study leads with the problem bound between ficction, imaginary and reality, according Wolfgang Iser

Keywords: Mexican Revolution; Modernization; Modernity; History of Literature; Juan Rulfo.
\end{abstract}

Artigo recebido em: 30/05/2018

Artigo aprovado em: 09/12/2018

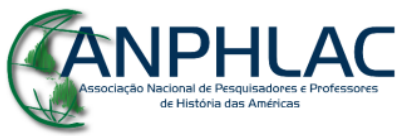


"Vine a Comala, porque me dijeron que acá vivía mi padre, un tal Pedro Páramo. Por eso vine a Comala."

Pedro Páramo, Juan Rulfo

\section{Em 1945, o escritor mexicano Juan Nepomuceno Carlos Pérez Rulfo Vizcaíno} (1917-1986), mais conhecido como Juan Rulfo, publicou seus primeiros escritos, que, mais tarde, compuseram a coletânea de contos, intitulada El llano en llamas (1953) ${ }^{3}$. Dois anos depois, publicou o romance considerado sua obra-prima, Pedro Páramo $(1955)^{4}$. Por fim, entre 1956 e 1958, Rulfo escreveu uma terceira obra, El gallo de oro, publicada apenas em $1980^{5}$. Essas três obras resumem o trabalho do romancista que, embora breve na totalidade de páginas, realizou grande impacto sobre o nicho editorial ${ }^{6}$ ocupado na época pela literatura latino-americana, bem como sobre os rumos desta, influenciando grandes escritores do boom literário, como Gabriel García Marques e seu Nobel, Cien años de soledad (LEVINE, 1971, p. 18-24). Rulfo deixou aos mexicanos e ao mundo uma narrativa que engendra uma memória, ainda que fictícia, sobre o campo do pueblo ${ }^{7}$ e da hacienda; do campesino e do caciquismo $^{8}$; da tradição e da modernidade; enfim, los recuerdos acerca do interior do México pós-revolucionário. Um México e, sobretudo,

3 A primeira tiragem foi de dois mil exemplares, era composto por quinze contos que foram publicados a partir de 1945, sendo Nos han dado la tierra o primeiro deles.

4 A escrita de Pedro Páramo durou cerca de sete anos, de 1947 a 1954 - quando entregou o original mecanográfico ao Centro Mexicano de Escritores -, como uma de suas cartas à esposa, Clara Aparício, comprova (VITAL, 2017).

5 Parte da crítica considera a obra como um romance ou conto. Em 1964, a obra foi adaptada para o cinema por Roberto Gavaldón, diretor, e Manuel Barbachano, produtor.

6 Na década de 1970, Ell llano en llamas atingiu cerca de 400 mil e Pedro Páramo 500 mil exemplares vendidos, com inúmeras edições e traduções.

7 Pueblo é a forma pela qual a sociedade mexicana se refere à sua comunidade camponesa, que é de forte cultura e tradição indígenas.

8 Caciquismo faz referência aos inúmeros caciques, chefes locais não-raramente detentores de grande extensão de terras, que durante a Revolução Mexicana levantaram-se em armas pela disputa do poder, fragmentado durante a fase armada da Revolução, determinada entre 1910 e 1920. José Carnobell (2002), por outro lado, considera que desde 1929, com a criação do Partido Nacional Revolucionário (PNR), a centralização do governo pelo Executivo na figura da presidência findara com as divergências e as disputas pelo poder. Tal efeito tornou-se mais agudo em 1938 com a transformação do PNR no Partido de la Revolución Mexicana (PRM) pelo governo de Lázaro Cárdenas (1934-1940) ao trazer para dentro do PRM setores populares mexicanos.

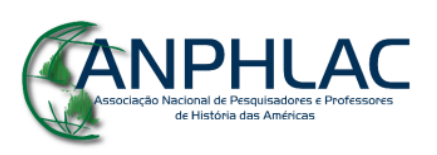

Revista Eletrônica da ANPHLAC, ISSN 1679-1061, №. 25, p. 222-251, Jul./Dez., 2018.

http://revista.anphlac.org.br 
uma Jalisco ${ }^{9}$, que fora palco de personagens impactadas pela violência da Conquista, pelo poder e arbitrariedade dos caciques, pelas transformações trazidas com a modernização, pela desestabilização política e a guerra durante a Revolução Mexicana (1910-1940), que deixara ao longo desse rastilho de pólvora um pueblo olvidado.

Dessa maneira, ressaltamos ao longo do artigo os laços e desatamentos entre a história e a literatura naquilo que concerne à historicidade da narrativa rulfiana como objetivo maior da investigação. Valorizamos, no entanto, o esforço e a sensibilidade contínuos e imprescindíveis para com a natureza da fonte. É dizer, ainda que a narrativa literária esteja submetida às intempéries de um tempo que lhe é externo, possui um tempo outro (diegese ${ }^{10}$ ) que lhe é interno e próprio, um tempo da ordem do narrado. Abordamos ainda fases que consideramos cruciais na formação do escritor e intelectual que fora Rulfo, bem como os efeitos causados pela Revolução Mexicana sobre sua trajetória e o desenrolar de seus efeitos entre 1940 e 1955. Por fim, apontamos como a obra do escritor se afasta do realismo das novelas de la Revolución ${ }^{11}$ e se consolida no realismo maravilhoso $^{12}$, levada por suas leituras acerca da história mexicana, da produção sociológica do Instituto Nacional Indigenista e por uma visão crítica e irônica sobre a política encabeçada pelo Partido Revolucionario Institucional (PRI).

9 Estado situado no Oeste mexicano, Jalisco tem grande importância não só econômica, mas cultural e histórica para o México: principal produtor de tequila, estado origem dos famosos mariachis e região de antiga presença espanhola, duramente marcada pelo conflito violento entre indígenas e colonizadores.

10 A diegese é formada pelas dimensões temporal e espacial que são próprias da narrativa, de maneira que não possui qualquer relação extratextual. Em Pedro Páramo, o tempo da diegese é, portanto, dúbio, fragmentado e não-linear. O espaço, por sua vez, quase não possui referência externa ao pueblo de Comala. Ele é, portanto, esse pueblo vazio, abandonado e esquecido num não-tempo, no qual fragmentos nãocontínuos sobrepõem um passado sobre o outro, criando certa confusão sobre o que é da ordem do presente e o que é da ordem do passado.

11 As chamadas novelas de la Revolución formam um subgênero literário mexicano, em geral produzido entre 1910-1930, cuja principal temática era o processo revolucionário mexicano e seus meandros. Nomes como Mariano Azuela e Martín Luíz Guzmán compuseram essa produção (GOMES \& ANDRADE, 2018, p. 56-81).

12 Apoiamo-nos na delimitação sugerida por Irlemar Chiampi, a qual valoriza o adjetivo "maravilhoso" em detrimento do "mágico", visto que o novo realismo hispano-americano não configurou uma dimensão apenas fantástica, mas reconfigurou um imaginário dos navegantes do século XVI projetado sobre a América. Nesse imaginário, a "maravilha" e o "maravilhoso" foram chaves-mestras não só para a tradução do que se via, como também para um impulso à Conquista. Acrescentamos que a mesma autora delimita o recorte temporal de produção do realismo maravilhoso entre 1941, publicação de Yawar fiesta, de José María Arguedas, e 1955, publicação da obra central à análise que este artigo pretende - apesar de não ignorar a forte influência de José Carlos Borges sobre a produção do período desde a década de 1930 (CHIAMPI, 2015., p. 19-29).

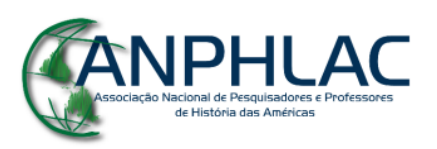

Revista Eletrônica da ANPHLAC, ISSN 1679-1061, №. 25, p. 222-251, Jul./Dez., 2018.

http://revista.anphlac.org.br 
Ato contínuo, levanta-se a reflexão sobre de que maneira a narrativa em Pedro Páramo traz uma temporalidade e relatos de uma memória, que é fragmentada e que se sustenta em uma ficcionalização da oralidade. A narrativa é formada, pois, por relatos marcados por expressões populares no México, derivadas quase sempre do nahuatl ${ }^{13}$, além de tal oralidade estar ligada a uma forma de transmissão do saber típica dos povos originários. Portanto, é fundamental o contraponto entre a perspectiva posta pelo realismo-naturalista das novelas de la Revolución e as transformações do novo romance trazido pelo realismo maravilhoso. Por exemplo, a temporalidade narrativa no primeiro é fechada e sustém uma dicotomia entre um mundo supostamente dividido entre o arcaico e o moderno. Ao passo que o realismo maravilhoso mobiliza trocas, resistências e influências concomitantes entre o urbano e o rural, o moderno e o arcaico e principalmente entre a linguagem oral e a linguagem escrita. Em uma ficção na qual o tempo se fecha para voltar a se abrir, de uma maneira que a voz do narrador não se imponha ao leitor e não defina um sentido único e linear da narrativa. Ao limite, o novo realismo hispano-americano efetuou:

a união de elementos díspares, procedentes de culturas heterogêneas, configurou uma nova realidade histórica, que subverteu os padrões convencionais da racionalidade ocidental [Isto é] não a invenção do imaginário do autor, mas a junção de elementos reais que singularizam a América no contexto ocidental (CHIAMPI, 2015, p. 32).

\section{A obra Pedro Páramo}

Antes de passarmos à análise propriamente dita, um pouco sobre o escritor.

Juan Rulfo nasceu em Pulco, interior de Jalisco. Perdeu o pai quando criança, assassinado em uma emboscada armada na madrugada de junho de 1923 por Guadalupe Nava a caminho de uma propriedade da família ${ }^{14}$, , situada onde hoje é San Pedro de Toxin, centro-sul de Jalisco. Em 1924, faleceu também o avô paterno, Severiano. Após a

13 Língua indígena de origem asteca.

14 No conto ;Diles que no me maten! (RULFO, 2004, p. 104-111), Rulfo insere na trama o motivo de morte do pai: o atrito com o invasor de terras, que durante a noite rompia a cerca para usar o pasto da propriedade dos Rulfo, apesar dos pedidos seguidos para que não o fizesse. Além disso, divide o nome do assassino, Guadalupe Nava, entre as duas personagens do conto: don Lupe Terreros (Lupe é o diminutivo para Guadalupe) e Juvencio Nava (VITAL, 2017).

\section{CANPHLAC}


perda do filho, pai do escritor, a avó paterna levou para Guadalaraja, capital de Jalisco, Rulfo e o irmão mais velho. A falta dos dois filhos somada à perda do marido e dos dois infelizes encontros com o assassino do esposo levou María Arías, mãe do romancista, a uma profunda tristeza e à morte em 1927, durante a Rebelión Cristera (MEYER, 2004; CAMIN \& MEYER, p. 114-119) ${ }^{15}$.

Na década de 1930, a educação do jaliscense foi atingida por um intenso debate acerca dos destinos da educação mexicana. O escritor começou o curso de Direito na Universidade de Guadalajara, mas não o concluiu, tendo desistido devido a uma greve que se estendeu por quase um ano e meio. Poucos anos depois, iniciou o curso da Faculdade de Filosofia e Letras na Cidade de México, apresentando interesse pela História, Geografia e Antropologia, que se consolidariam em 1962 (VITAL, 2017). Nessa data, ingressou como redator no Departamento de Publicações do Instituto Nacional Indigenista (INI), hoje Comissão Nacional para o Desenvolvimento dos Povos Indígenas (CDI), onde trabalhou de forma permanente até 1986. Ao longo de sua carreira no Instituto, aliás, houve grande impulso no número de publicações da revista da instituição, Acción Indigenista, 153 números entre 1953 e 1976 (TAPIA, 2017).

Passamos à obra Pedro Parámo (1955) que, como já foi dito, será o centro de nossa análise ${ }^{16}$, que consideramos condensar a riqueza de Rulfo como escritor, que não está apenas nas personagens ou na história que desenvolve, mas, principalmente, em sua urdidura.

Vine a Comala porque me dijeron que acá vivía mi padre, un tal Pedro Páramo. Mi madre me lo dijo. ${ }^{17}$

15 Ocorrida durante a Revolução Mexicana, a Rebelião Cristeira (1926-1929) marcou as regiões do Oeste mexicano, onde está situado Jalisco. Fora caracterizada pela resistência armada popular e camponesa frente à decisão do Estado, apoiado na Constituição de 1917, de não só afirmar sua laicidade, mas também administrar as propriedades da Igreja no México. Padres e bispos foram expulsos do território nacional, e o conflito entre a população e as tropas oficiais fora sangrento. Ao longo do conflito estiveram, de um lado, os camponeses que lutavam pelo direito de culto religioso e pelo acesso à terra, intitulados cristeros; e, do outro, o Estado e pequenos e médios proprietários (rancheros), aliados ao exército federal em defesa da laicidade e da propriedade agrária, conhecidos como agraristas. Ressaltamos, contudo, que o debate historiográfico acerca da natureza e composição do conflito é denso e remonta à década de 1930 (SILVA, 2009; BUTLER, vol. LII, n. 2, oct-nov, 2002).

16 No entanto, em momento que for conveniente abordaremos outros textos de Rulfo.

17 As palavras em negrito daqui em diante são do autor.

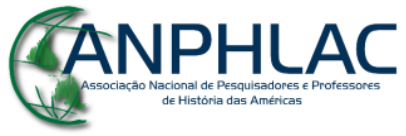

Revista Eletrônica da ANPHLAC, ISSN 1679-1061, №. 25, p. 222-251, Jul./Dez., 2018.

http://revista.anphlac.org.br 
A epígrafe do presente artigo, frase inicial da tragédia ${ }^{18}$ do pueblo de Comala $^{19}$, é a fala de uma personagem inicialmente não identificada. O que se apreende é que se trata de um filho ou filha ${ }^{20}$ de alguma mulher, de seu paradeiro e de estar em tal pueblo, porque a mãe disse que ali se encontrava o pai desconhecido, como a expressão "un tal" faz entender. A voz ${ }^{21}$ nesse momento diz de maneira discreta que já está no pueblo onde a mãe nascera e vivera quando jovem, a partir do verbo "vine" no passado perfeito da primeira pessoa do singular e do advérbio de lugar "acá". Além disso, pela maneira como o filho de identidade desconhecida se refere ao pai, deduz-se que está em questão a orfandade e o abandono paterno. O filho teria, por conseguinte, uma identidade "pela metade" no que diz respeito a seu passado e sua origem. Em seguida, ele diz:

Y yo le prometí [a mãe] que vendría a verlo [Pedro Páramo] en cuanto ella muriera. Le apreté sus manos en señal de que lo haría, pues ella estaba por morirse y yo en un plan de prometerlo todo.

O filho que narra o momento de morte da mãe conta a alguém — como é possível perceber pelo sujeito da narrativa na primeira pessoa do singular no trecho acima como prometeu ir em busca do tal pai no impulso do momento ${ }^{22}$, justificativa para ter chegado à Comala. No entanto, recebeu o conselho materno, carregado de ressalvas, que definia a razão da demanda materna e como deveria proceder ao encontrar o pai:

No vayas a pedirle nada. Exígele lo nuestro. Lo que estuvo obligado a darme y nunca me dio... El olvido en que nos tuvo, mi hijo, cóbraselo caro (RULFO, 2015, p. 73).

18 Patrick Dove (2001) analisa como a trama da obra readapta a tragédia grega: a mãe que demanda do filho vingança sobre o pai; aquele, no entanto, falece durante sua jornada. O pai, por fim, é assassinado por um filho outro também num passado outro.

19 Comala é um pueblo habitado majoritariamente por camponeses, situada entre algumas propriedades agrárias. No entanto, após a anexação ilegal e escusa das demais terras à Media Luna, cujo dono é Pedro Páramo, os moradores de Comala passam a viver como satélites em torno daquela. Todos caem sob o domínio e vontade de Pedro Páramo, e conforme este abandona gradativamente seus negócios, devido à sua frustração amorosa com Susana san Juan, Comala ingressa numa miséria cada vez mais profunda.

20 O nome do filho, Juan Preciado, é identificado apenas na página 125.

21 Por voz entendemos uma dimensão interna do texto, que não diz sobre o autor, mas sobre um narrador ou não que fala a um narratário (também interno ao texto) e estrutura ou não um sujeito próprio do texto (BARTHES, 2004).

22 No último parágrafo da mesma página aquele que narra confessa seu desinteresse pela promessa: "Pero no pensé cumplir mi promessa".

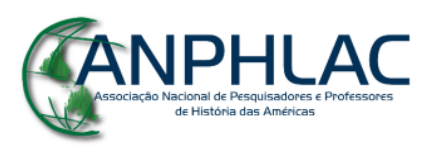

Revista Eletrônica da ANPHLAC, ISSN 1679-1061, №. 25, p. 222-251, Jul./Dez., 2018.

http://revista.anphlac.org.br 
A demanda da mãe tem um tom de vingança em face do abandono e do esquecimento da parte do homem que fora seu marido. Em um fragmento mais avançado da obra, é revelado o nome materno, Dolores Preciado (RULFO, p. 105), e a razão do seu desejo de vingança: a perda de sua propriedade por via do pedido de casamento feito às pressas por Pedro Páramo como parte de um plano deste para alavancar seu domínio, tomando-lhe as terras (RULFO, p. 106-108). Enfatizamos a tensão existente na exigência da mãe que possui, de um lado, o desejo íntimo de recuperar o que era seu e reparar a humilhação pela qual passou e, de outro, a preocupação para com o filho. Se no primeiro momento a mãe usa o pronome possessivo "nuestro", no segundo, utiliza o pronome " $m e$ " e, de novo, retorna à primeira pessoa do plural, apontando novamente a uma coletividade. Porém, a ira com que encerra a fala, "cóbraselo caro", cria um contraste entre um senso de justiça e um desejo individual de vingar-se do opressor usando-se de violência. Nas entrelinhas, paira um sentido trágico de parricídio.

A procura pelo pai, nesse ínterim, toma uma dimensão de busca por uma identidade que se perdeu em um passado que não o seu, mas o da mãe. Isto está ligado à problemática da identidade posta pela indagação "o que eu sou?". Trata-se de um pensamento não só mexicano, mas também aquele que singulariza a cultura latinoamericana 5491670491265463 (ALTAMIRANO, 2005). É, por excelência, um conflito que se instaura com a Conquista, mais tarde com as independências e com o anseio pelo progresso e pela entrada em uma modernidade de face europeia. Instaura-se uma indagação: "o que somos perante os demais ex-colonizadores, já que somos diferentes, ainda que semelhantes a eles". Aqui cabe, outrossim, a forma como o próprio escritor conta a história de Jalisco durante a Conquista espanhola:

Yo soy de una zona donde la conquista española fue demasiado ruda. Los conquistadores ahí no dejaron ser viviente. Entraron a saco, destruyeron la población indígena, y se establecieron. Toda la región fue colonizada nuevamente por agricultores españoles. Pero el hecho de haber exterminado a la población indígena les trajo una característica muy especial, esa actitud criolla que hasta cierto punto es reaccionaria, conservadora de sus intereses creados [...] sus descendientes, siempre se consideraron dueños absolutos. Se oponían a cualquier fuerza que pareciera amenazar su propiedad. De ahí la atmósfera de terquedad, de resentimiento acumulado desde siglos atrás [...] (RULFO, 1973).

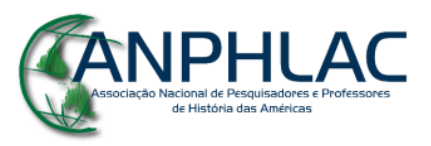

Revista Eletrônica da ANPHLAC, ISSN 1679-1061, №. 25, p. 222-251, Jul./Dez., 2018.

http://revista.anphlac.org.br 
A jornada de Juan Preciado ${ }^{23}$ em busca do pai mergulha aos poucos em uma narrativa que diz sobre uma otredad ${ }^{24}$ (DOVE, 2001). Essa otredad é encontrada entre aqueles que habitam o pueblo de Comala, que do nahuatl significa lugar sobre brasas ${ }^{25}$. Durante o caminho, aliás, a personagem dá uma pista da natureza daquele pueblo: "aquello está sobre brasas de la tierra, en la mera boca del Infierno" (RULFO, op. cit., p. 75). Em Comala, Juan Preciado depara-se com um lugar marcado pelo paradoxo de uma imensidão vazia - nas palavras de Rulfo, pela terquedad, pelo resentimiento —, na qual o tempo reverbera nas coisas, quais ecos de tempos passados que se sobrepõem e se fazem relembrar, infinitamente. Como no trecho:

- Este pueblo está lleno de ecos. Tal parece que estuvieran encerrados en el hueco de las paredes o debajo de las piedras. Cuando caminas, sientes que te van pisando los pasos. Oyes crujidos. Risas. Unas risas ya muy viejas, como cansadas de reír. Y voces ya desgastadas por el uso [...] Pienso que llegará el día en que estos sonidos se apaguen (RULFO, op. cit., 109).

Esse pueblo esquecido é habitado por ruídos, vozes e murmúrios de um vivido. Embora os habitantes estejam mortos, eles vivem como uma memória que ecoa pelo espaço e materialidade de Comala, nas paredes, debaixo das pedras, nos ruídos.

Ao fim da primeira parte da narrativa, Preciado termina o relato de sua jornada à Comala, a qual finda com a sua própria morte. Daí em diante a narrativa se pulveriza em uma pluralidade de vozes — nas quais Juan Preciado se confunde - que do túmulo murmuraram em fragmentos o que viveram em Comala sob o domínio do pai e da vingança que aquele filho buscara.

O tempo em Pedro Páramo é um tempo difuso, enevoado, semelhante ao sonho - palavra que, inclusive, se repete diversas vezes na narrativa. Os relatos ora se

23 Gostaríamos de ressaltar que não consideramos Juan Preciado protagonista da obra. Se ele o for, não mantém essa posição para além da primeira metade da trama, a justificativa será desenvolvida ao longo da análise.

24 Entendemos o termo otretad no sentido de um outro, uma identidade outra. A população sobrenatural de Comala representa esse outro lado de uma mesma moeda, a modernidade mexicana. A obra de Rulfo demonstra como não é possível dizer sobre a modernização conflituosa do México sem abarcar o campo e, ao cabo, a população indígena.

25 A palavra Comala deriva de comal, uma espécie de braseiro ou forno típico utilizado para assar tortillas, populares na alimentação mexicana.

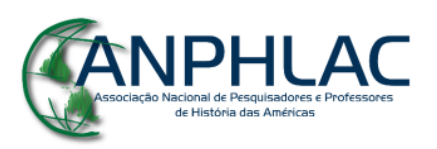

Revista Eletrônica da ANPHLAC, ISSN 1679-1061, №. 25, p. 222-251, Jul./Dez., 2018.

http://revista.anphlac.org.br 
intercalam, ora se perdem nas brumas da ilusão. Assim o é não somente pelo fato de se tratar de uma narrativa que é mantida por inúmeros relatos póstumos sobre um vivido, senão porque articula, sobretudo, uma narrativa del recuerdo e del olvido. Como sente Preciado:

\section{La madrugada fue apagando mis recuerdos.}

Oía de vez en cuando el sonido de las palabras, y notaba la diferencia. Porque las palabras que había oído hasta entonces, hasta entonces lo supe, no tenían ningún sonido, no sonaban; se sentían; pero sin sonido, como las que se oyen durante los sueños (RULFO, p. 115).

A recordação e o esquecimento estão imbrincados na narrativa, e dão forma àquilo que se conta: para lembrar é preciso esquecer, pois esquecer algo já implica a sua lembrança, que é da ordem do futuro (DELEUZE, 2003). O esquecimento é senão a urdidura da memória. A narrativa de Rulfo tem esse poder, produzir a lembrança no ato da leitura, denunciando o esquecimento e o silêncio que assolaram o pueblo — denúncia que ainda se faz necessária, aliás. Nessa tensão, entre esquecimento e memória, elaborase um conjunto que aos poucos confere forma à figura de Pedro Páramo, ao passo em que se cria um panorama da quimera que fora a Revolução Mexicana a partir de Comala, essa personagem confrontada pela modernização.

Ao fim da obra, esses recuerdos póstumos narram a morte do cacique Pedro Páramo. Este não fora assassinado pelo filho que fora enviado pela mãe, mas por um outro filho bastardo, anos antes da ida do primeiro. Tal parricídio coloca um fim na alegoria que é Pedro Páramo, uma alegoria do poder e do Estado mexicanos sob governo do PRI. Esse partido, fruto de uma reorganização e estabilização política, que emparelhara a Revolução Mexicana a uma ideia de modernidade e às instituições modernas que, embora nunca consolidada, ainda estaria por vir. Sempre reatualizada e adiada.

Ao fim, Pedro Páramo: Dio un golpe contra la tierra y se fue desmoronando como se fuera un montón de piedras (RULFO, p. 186). Um monte de pedras, como os recuerdos, que construíram ao longo da narrativa essa figura de poder, arbitrária e violenta a partir das lembranças de um pueblo morto. Este que minguou sob a violência

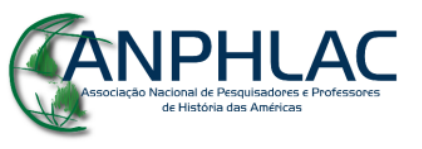

Revista Eletrônica da ANPHLAC, ISSN 1679-1061, №. 25, p. 222-251, Jul./Dez., 2018.

http://revista.anphlac.org.br 
do cacique, tornou-se, por fim, a solidão daquele e que, como sugere o título da obra, terminou seus dias de desmando como uma pedra num páramo, como algo bruto isolado no próprio deserto que cultivou.

\section{Ainda sobre a ficção e los recuerdos em Pedro Páramo}

Segundo José Carlos González Boixo a trama de Pedro Páramo é desenvolvida entre os anos de 1865 e 1927(RULFO, 2015, p. 189) ${ }^{26}$, o que compreende o período entre o nascimento e a morte do cacique Pedro Páramo. A narrativa tem como pano de fundo, portanto, o processo de modernização encabeçado pelo governo ditatorial de Porfírio Díaz e a fase mais violenta do período revolucionário, que, de certa maneira, se estabilizou com a eleição do caudillo Plutarco Elías Calles (1924-1928). A influência política deste último ficou conhecida como callismo e foi fundamental para a fundação de uma primeira versão do PRI, o Partido Nacional Revolucionário (PNR) em $1929^{27}$.

A obra do escritor jaliscense, à sua maneira, engendra uma memória, composta por testemunhos que contam uma versão distinta e na contramão do discurso oficial sobre o período acima mencionado. Ainda que sejam fictícios, tais testemunhos não deixam de dizer algo sobre aquele passado e estão vinculados ao tempo da escrita. Por isso, é crucial que discutamos as relações entre ficção e história, bem como a imagem que a memória articulada pelos relatos dos habitantes de Comala produz.

Ao mesmo tempo, acerca da investigação histórica a partir da ficção literária, embasamos a pesquisa na concepção de Wolfang Iser (2002). Este analisou as relações entre a realidade e a ficção por meio do que ele denominou de "atos de fingir". Seu objetivo foi demonstrar que o texto ficcional - aqui, a narrativa de Juan Rulfo — não é mera narrativa isolada do real ou fechada em si, pelo contrário. Elementos do real são incorporados e organizados pela e na narrativa por intermédio de um terceiro partícipe de

26 Segundo Boixo, essa possível temporalidade — que não é a da trama, vale lembrar — se inicia com o nascimento e a morte de Pedro Páramo. Para determinar tal data, o crítico parte da morte de Susana san Juan: quando esta ainda era viva, o personagem Damasio se une às tropas villistas a pedido do cacique, o que nos leva por volta de 1914. Na data de morte de Susana, no entanto, Damasio retorna dizendo "ahora somos carrancistas [...] andamos con mi general Obregón" (RULFO, p. 179). O recorte e justificativa de Boixo encontra-se no apêndice feito à $27^{\mathrm{a}}$ edição da obra, utilizada para escrita do presente artigo.

27 Retornaremos a esse assunto mais à frente.

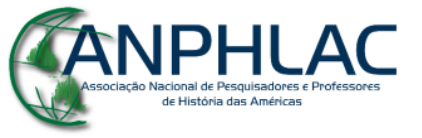

Revista Eletrônica da ANPHLAC, ISSN 1679-1061, №. 25, p. 222-251, Jul./Dez., 2018.

http://revista.anphlac.org.br 
seu sistema, o imaginário. Este seria o objeto da configuração ordenada pelos "atos de fingir" (seleção, combinação e desnudamento da ficção), de maneira a conferir ao imaginário um referencial no real, ou, nas palavras do autor, um "predicado de real", mas que, em um segundo momento, retorna sobre o real.

A narrativa ficcional, ainda que dê um significado distinto a elementos de um real anterior, produz a partir da leitura um sentido de real ou um "acontecimento de experiência". Em suma, o imaginário realiza a ficção ao mesmo tempo em que irrealiza o real. Rulfo, por conseguinte, mobilizou uma memória e um imaginário, que não necessariamente são apenas individuais ou subjetivos, para compor a narrativa dos camponeses em seu texto. Nas palavras do autor:

Una mentira. La literatura és una mentira que dice la verdad [...] Ahora hay una diferencia importante entre mentira y falsedad. Cuando se falsean los hechos se nota inmediatamente lo artificioso de la situación. Pero cuando se está recreando una realidad en base a mentiras, cuando se reinventa un pueblo, es muy distinto (RULFO, 1996, apud MOREIRA, 2012, p. 222).

Dessa forma, a Comala imaginada por Rulfo, apesar de ser uma cidade existente no México e trazer características próprias de um pueblo mexicano, não se trata de um real ou de uma dimensão autobiográfica. Porém, a obra de Rulfo possibilita, com base em recursos da narrativa, que o leitor sinta o peso da solidão, da miséria, da arbitrariedade do cacique e o mistério e a dor da morte que assolaram os pueblos mexicanos durante e após a Revolução. Permite, em paralelo, que as contradições da modernização mexicana e dos projetos de país, sobretudo do PRI, venham à baila.

Há, portanto, duas Comalas na trama: a da mãe, em um passado de atmosfera edênica $^{28}$, e a do filho, como um passado presentificado pelos relatos de uma violência

28 Salientamos que uma outra memória acerca dessa Comala edênica é a de Pedro Páramo, já adulto, relembrando sua infância e de seu amor por Susana san Juan. Uma infância pobre, mas em um lugar tranquilo de se viver, e que aos poucos se cerca de violência e morte. Um desses fragmentos está relacionado ao assassinato do pai de Rulfo: Pedro Páramo, pela madrugada, recebe da mãe a notícia da morte do pai. A fala final, como uma pergunta cheia angústia, feita pelo filho já adulto, remete, por sua vez, à morte da mãe de Rulfo, que morrera três anos após o assassinato do marido: "— ¿Y a ti quién te mato, madre?" (RULFO, 1955, p. 93-94). Aproveitamos para dizer que não tratamos tais trechos como elementos meramente autobiográficos. Apoiamo-nos aqui no conceito de "biografema", segundo Barthes, aquele é

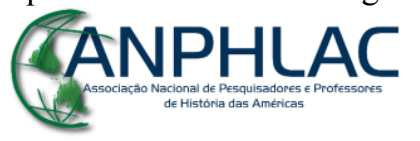

Revista Eletrônica da ANPHLAC, ISSN 1679-1061, №. 25, p. 222-251, Jul./Dez., 2018.

http://revista.anphlac.org.br 
vivida, que é, portanto, da ordem da memória. A lembrança materna se faz lembrar em fragmentos naquilo que o filho vê, como tal trecho da obra nos permite conceber:

Yo imaginaba ver aquello a través de los recuerdos de mi madre [...] Siempre vivió ella suspirando por Comala, por el retorno; pero jamás volvió. Ahora yo vengo en su lugar. Traigo los ojos con que ella miró estas cosas, porque me dio sus ojos para ver (RULFO, 2017, p. 74).

Tal ambiguidade corta a narrativa e cria um sentido de contraste com aquilo que Juan Preciado presencia em sua jornada ao pueblo deixado pela mãe. A descrição do filho que vê uma Comala abandonada, onde a morte se assentou, é interrompida pela voz da mãe que conta sobre uma Comala outra, de natureza edênica, à maneira das cartas de relación que contavam sobre as maravilhas e os mitos de um Novo Mundo no século XVI:

Sentirás que allí uno quisiera vivir para la eternidad. El amanecer; la manaña; el mediodía y la noche, siempre los mismos; pero con la diferencia del aire. Allí, donde el aire cambia el color de las cosas; donde se ventila la vida como si fuera un murmullo; como si fuera un puro murmullo de la vida... (RULFO, p. 126).

A mãe em vida, antes de partir de seu pueblo, conhecera "un murmullo de la vida", o filho, no entanto, teve outra sorte, como diz após esse lapso de memória acima: "Me mataron los murmullos" (RULFO, p. 126). Juan Preciado parte lembrando de como a mãe lhe contara sobre a "llanura verde, algo amarilla por el maíz maduro", de uma Comala "blanqueando la tierra, iluminándola durante la noche" (RULFO, p. 74). No entanto, ao longo da jornada em direção o que pensava ser a vida, adentra em um cenário de morte, depara-se com uma Comala triste, onde "todo parecia estar como en espera de algo" (RULFO, p. 75), à espera de uma modernidade prometida ou de uma Revolução supostamente ainda por se concluir. Na década de 1940, após um período de extrema violência e desestabilização política, o qual continuava sendo mobilizado como o início de mudanças e de um futuro que alcançaria a todos, a Comala de Rulfo surgia como um lugar de um passado ainda presente no México.

antes um signo do que um eu transcrito. Sendo signo, recria seus significados, sobretudo no ato da leitura, e, portanto, não erige um sujeito, mas fragmenta-o (BARTHES, 1971, p. IX-XIX).

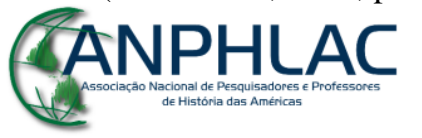

Revista Eletrônica da ANPHLAC, ISSN 1679-1061, №. 25, p. 222-251, Jul./Dez., 2018.

http://revista.anphlac.org.br 
$\mathrm{Na}$ passagem a seguir, o retrato da mãe, que Juan Preciado leva no bolso, apresenta uma metáfora da memória, e indica por seus agujeros a dimensão opaca dos recuerdos e do olvido que formam a narrativa rulfiana:

Era un retrato [da mãe] viejo, carcomido en los bordes [...] me lo había encontrado en el armario de la cocina, dentro de una cazuela llena de yerbas: hojas de toronil, flores de Castilla, ramas de ruda [...] Mi madre siempre fue enemiga de retratarse. Decía que los retratos eran cosa de brujería. Y así parecía ser; porque el suyo estaba lleno de agujeros como de aguja, y en dirección del corazón tenía uno muy grande donde bien podía caber el dedo del corazón (RULFO, p. 76).

O retrato da mãe sustenta a condição da memória, como um jogo entre esquecimento e lembrança, à maneira de lacunas criadas pelo tempo. Um passado carcomido, mas que ainda se faz lembrar e que é reconfigurado no presente (DELEUZE, 2003). Por outro lado, esse signo que Juan Preciado leva consigo no intuito de rememorar a mãe jovem, faz com que ele remeta não aos traços físicos, mas a uma crença que Dolores Preciado, sua mãe, possuía. Uma crença conflituosa com o que a fotografia apresentava de desconhecido, lançando sobre ela o mistério da alma e da bruxaria. Com a pretensão de se proteger dessa modernidade, a mãe escondeu seu único retrato entre ervas e folhas de arruda, como uma mescla de superstição e técnica. O filho também não parece certo da natureza da fotografia nem da crença materna, visto que, como em uma prática comumente relacionada ao vodu, pondera a razão da mãe e relaciona as marcas do tempo a espetadas de agulha.

Gostaríamos de enfatizar aqui, por conseguinte, o processo transculturador, fundamental à compreensão das transformações da narrativa latino-americana entre o realismo-naturalista e o realismo maravilhoso. É pela transculturação que elementos idiossincráticos de culturas distintas são abarcados e reconfigurados sob uma nova forma, que envolve o popular e o erudito, o moderno e o arcaico. O que resulta em uma nova e outra poética imbrincada à modernidade. No caso da América Latina, envolveu também os mitos fundadores de uma sempre procurada e questionada identidade latino-americana — como analisado acima (RAMA, 2001, p. 11-13 e 209-238).

\section{CANPHLAC}


Ato contínuo, Pedro Páramo é permeado por uma relação maleável entre superstição/religiosidade e técnicas, como a fotografia supracitada, não em um sentido de oposição, mas em um modo de influência e transformação mútuas. Ainda que a mãe temesse a foto, ela deixou-se fotografar, bem como guardou o retrato. Ao mesmo tempo, o filho, com ares de desconfiança sobre a mãe, não deixa de considerar, mesmo que ironicamente, que talvez ela estivesse certa sobre o poder místico por trás daquela forma de lembrar o passado. Curioso notar que tal qual o filho, essa recordação mecanizada e, sendo memória, resiste a descrições diretas e recai em processos metafóricos (ASSMANN, 2001, p. 161-163) — da mãe imerge em um mundo onde o passado só pode ser lembrado se contado, isto é, narrado oralmente. A oralidade ficcionalizada na obra surge como uma forma poderosa de conhecimento de um tempo pretérito, de tal forma que o filho não descreve a aparência da mãe, mas conta algo sobre sua visão de mundo que acaba por defini-la.

Ato contínuo, por meio dos "atos de fingir", Rulfo não está isento de uma intencionalidade, a qual está relacionada, também, à percepção do autor. O escritor confere ao texto uma interpretação que lhe é própria, ainda que partindo de um contexto. Isso pode ser comprovado pelos elementos que ele selecionou, de sua memória ou não, e por aqueles que ele escolheu ou não ausentar. Em entrevista concedida ao programa televisivo mexicano A Fondo em 1977, o escritor expõe esse processo acerca de sua narrativa e o México que conheceu:

Estos personajes se me han grabado. Y los he tenido que recríalos, ¿no? No pintar como ellos eran, sino yo tenía que revivirlos, de alguna forma, imaginándolos, como yo viera aquello que fuera. Entonces, ese proceso de creación que siga esas cosas no es propiamente de la realidad, tomando las cosas de la realidad, sino imaginando-las [...] Lo que hay de real es la ubicación. Ubicando el personaje, ya le doy yo cierta realidad aparente, ¿no? Y después tengo que inventarle, también, el modo de hablar, de expresarse. Porque ellos no se expresan así (RULFO, 1977).

A partir dessa fala, percebemos, portanto, como o real é ressignificado pelo olhar e reordenado pelo imaginário. Boixo (1997) demonstra ao citar o conto Nos han dado la tierra, que a "estética do rural" em Rulfo é muito mais seca e desolada que a paisagem de

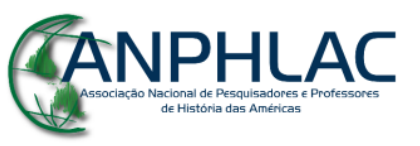

Revista Eletrônica da ANPHLAC, ISSN 1679-1061, №. 25, p. 222-251, Jul./Dez., 2018.

http://revista.anphlac.org.br 
Jalisco é de fato. Sua intenção, pois, não é apenas o testemunho daquilo que provavelmente viu - como declarava ser uma das referências de Pedro Páramo seu retorno, trinta anos mais tarde, ao seu pueblo de origem e ali o ter encontrado completamente abandonado e esquecido - mas (re)apresentar - não de novo, mas de outra forma - a dor e a solidão da condição humana e do campo mexicano, sobretudo de Jalisco.

Relacionado a isso é possível perceber como a obra do escritor mexicano articula em sua narrativa características que surgem na literatura latino-americana da década de 1920, a confusão entre narrador e protagonista e a supressão do "eu", a incorporação de expressões populares e da língua náuatle, a reconfiguração dos mitos fundadores da América, sobretudo do México (ECHEVARRÍA, 2000) ${ }^{29}$. Uma narrativa que se fez resistir diante da modernidade, que, segundo Ángel Rama (2001), é externa e, em seguida, é interna na direção das cidades para o campo, mas que cumpriu a função de resistir e de se rearticular às influências culturais. $O$ retrato da mãe aparece aí como essa junção de uma técnica moderna, criada no intuito de inscrever um momento vivido, mas que é, ao mesmo tempo, tomada como prática mística, realizada sob o efeito do, sobrenatural que é da ordem do fantástico (outra característica articulada pelo realismo maravilhoso).

\section{Juan Rulfo e a narrativa latino-americana}

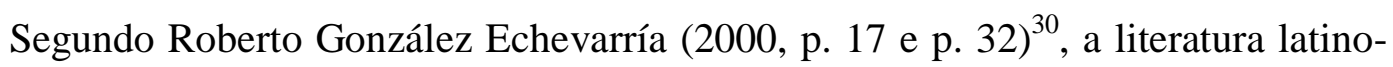
americana engendrou, em função de cada período, formas de discurso não-literárias e de caráter documental: os relatos de viagem e as cartas de relación, o discurso da lei, do método científico e o discurso antropológico. Essas várias formas de perspectiva sobre o mundo fazem parte do Arquivo ${ }^{31}$. Os enunciados que aí compõem de maneira própria e

29 Estabeleceremos tal discussão nas páginas seguintes.

30 Agradecer ao prof. dr. Emílio Carlos Roscoe Maciel, quem, com incrível prontidão, respondeu ao meu pedido e me indicou tal leitura.

31 Arquivo é um conceito elaborado por Michel Foucault na Arqueologia do Saber. Segundo Foucault: “O arquivo é, de início, a lei do que pode ser dito, o sistema que rege o aparecimento dos enunciados como acontecimentos singulares. Mas o arquivo é, também, o que faz com que todas as coisas ditas não se acumulem indefinidamente em uma massa amorfa, não se inscrevam, tampouco, em uma linearidade sem

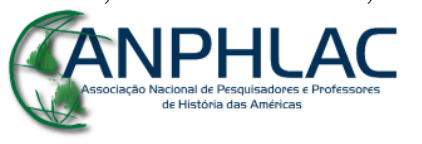

Revista Eletrônica da ANPHLAC, ISSN 1679-1061, №. 25, p. 222-251, Jul./Dez., 2018.

http://revista.anphlac.org.br 
continuamente ressignificada são incorporados pelo romance, conferindo a este um efeito de verdade dentro daquilo que é ou não legítimo em um contexto específico.

No caso da América Latina, a narrativa literária apresentou ao longo do tempo uma dimensão documental, por exemplo: Historia de Mayta (1984), de Mario Vargas Llosa, Os sertões (1902), de Euclides da Cunha, o Facundo (1845), de Sarmiento e outros. Ao mesmo tempo em que recriou mitos fundadores de uma América Latina, como a questão da identidade, que permeia, como citada acima, tanto Cien años de soledad quanto Pedro Páramo. Uma espécie de tópica do pensamento latino-americano: "o que é ser latino-americano?” Ou melhor, “o que é ser mexicano?”. Essa reconfiguração de discursos e de um imaginário, quase sempre coloniais, projetados sobre culturas e povos violentamente colonizados forma essa poética do realismo maravilhoso. O discurso antropológico foi um desses discursos nas primeiras década do século XX cujas pretensões e perspectivas o novo romance hispano-americano, sobretudo a obra de José Carlos Borges, subverteu.

A partir de 1920, as novelas modernas, conhecidas como novelas de la tierra ou novelas telúricas — semelhantes ao romance regionalista brasileiro das primeiras décadas do século $\mathrm{XX}$-, utilizaram outro tipo de forma discursiva: o discurso antropológico. Neste, não é mais a natureza o objeto, mas a linguagem e o mito. Para compreender o outro na perspectiva antropológica, é necessário entender a própria cultura em que se está inserido para, em seguida, desaparecer-se no discurso do método. O distanciamento, um processo cuja contrapartida se encontra na literatura latino-americana moderna, entranha uma espécie de retraimento do eu.

A criação de diversos institutos de antropologia e sociologia pela América Latina foi coetânea às novelas telúricas. No caso do México, foi criada em 1917 a Direção de Estudos Arqueológicos e Etnográficos, sob direção do antropólogo Manuel Gamio (18831960), cujo Projeto Teotihuacan durara oito anos (1916-1924). Este teve como objetivo a "aculturação" e assimilação dos indígenas a um mundo moderno com base no ensino do castelhano e da educação elementar. Vê-se um esforço, pois, com o apoio do Estado, em

ruptura [...] Longe de ser o que unifica tudo o que foi dito no grande murmúrio confuso de um discurso, longe de ser apenas o que nos assegura a existência no meio do discurso mantido, é o que diferencia $o s$ discursos em sua existência múltipla e os especifica em sua duração própria" (FOUCAULT, 1969, p. 147).

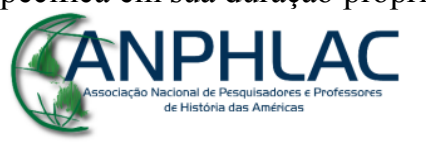

Revista Eletrônica da ANPHLAC, ISSN 1679-1061, №. 25, p. 222-251, Jul./Dez., 2018.

http://revista.anphlac.org.br 
compreender e inserir os remanescentes dos povos originários em uma sociedade capitalista e industrial, necessitada de trabalhadores. Nessa perspectiva, os indígenas mexicanos foram submetidos a uma ideia de mestiço e, em última instância, de camponês (LANDA, 2010, p. 57) ${ }^{32}$. Em 1948, a Direção de Estudos Arqueológicos se transformou no Instituto Nacional Indigenista (INI), no seio do qual o indigenismo moderno mexicano seria desenvolvido sob a direção do arqueólogo Alfonso Caso (1896-1970). Este em 1962, com a saída do historiador Gastón García Cantú (1917- 2003) — que conhecera e indicara Rulfo por seu trabalho como fotógrafo - convidou o escritor jaliscense para participar do Instituto. Juan Rulfo ingressou, então, como editor no INI, onde se deparou com obras como, por exemplo, Medicina y magia. El processo de aculturación en la estrutura colonial (1963) do antropólogo mexicano Gonzalo Aguirre Beltrán (19061996) (VITAL, 2017, p. 280-286).

De acordo com Echevarría (2000, p. 40), “a antropologia é uma das vias através das quais a cultura ocidental perfila e define indiretamente sua própria identidade cultural". Essa identidade, da qual o antropólogo supostamente esforça-se por livrar-se, domina as "culturas não históricas", isto é, envolve-as e lhes confere um sentido segundo uma perspectiva vizinha à europeia, mediante o conhecimento científico, fazendo delas seu objeto de estudo.

A antropologia permite a tradução de uma cultura outra à linguagem do Ocidente ou do mundo moderno, enquanto este nesse processo estabelece sua própria forma de conhecimento do outro por intermédio de uma espécie de suposta aniquilação do eu. Pois, somente estando consciente da existência do outro, o pensamento ocidental pode pretender remontar-se à origem do ser.

No caso do novo realismo hispano-americano, coloca-se em questão uma ideia de América anterior à Conquista espanhola. O desejo de uma volta ao passado - que é impossível - , para explicar uma sociedade antes do impacto cultural e da violência da colonização, em um começo no qual a mitologia ainda era teogonia. Para tanto, a antropologia busca resquícios desse passado no presente, em um mundo contemporâneo

32 Agradecer ao prof. dr. Luiz Estevam de Oliveira Fernandes pela referência.

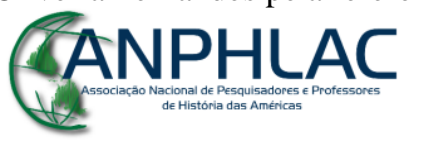

Revista Eletrônica da ANPHLAC, ISSN 1679-1061, №. 25, p. 222-251, Jul./Dez., 2018.

http://revista.anphlac.org.br 
de naturais que ainda sobrevivem, e o realismo maravilhoso não deixou de se apropriar e reinventar tal discurso.

A novela latino-americana moderna incorpora essa forma de enunciação para fazer ecoar, sobretudo, a voz do que seria o indígena no campesino, o que também está relacionado à ficcionalização da oralidade na obra Pedro Páramo e na narrativa rulfiana. Há uma síntese entre o conhecimento oral e o discurso científico antropológico. É, por conseguinte, a partir da narrativa literária na primeira pessoa do singular, na qual aquele que narra é também protagonista, que, para Echevarría, o romance latino-americano moderno reatualiza as bases da história da América Latina e seu mito originário a fim de ver a si mesma como o outro que ainda habita o começo.

Seu cerne é o arquétipo da identidade latino-americana ou a busca por ela como analisado acima neste artigo. Como Rama e Echevarría afirmam, os mitos são reatualizados sempre que a narrativa se transforma em um dado momento, oferecendo sentido ou resistindo a certas perspectivas acerca da própria América e de sua cultura. Rulfo, como um dos romancistas que se enquadram no realismo maravilhoso, reconfigurou tais mitos de um imaginário produzido sobre povos e culturas colonizados, singularizando a cultura e a sociedade mexicanas.

Para além do narrador-protagonista típico de um discurso antropológico, bem como de uma ficcionalização da oralidade, a narrativa rulfiana articula nesse sentido outras relações com tal Arquivo. Neste está incluso o discurso da lei e o poder da palavra escrita (RAMA, 1998; e GREENBLATT, 1996), como nas cartas de relación, cruciais para a reprodução - e seu estudo — de certos mitos fundadores da América ou, então, o chamado Novo Mundo do século XVI. Hoje, essas cartas possibilitam a análise de como se aplicava sobre lugares e culturas desconhecidas um imaginário, de maneira genérica, europeu, embora este fosse - e foi durante longa data - entendido como uma reprodução verídica acerca do que entendemos por América e seus povos.

Além do passado edênico — um dos mitos do século XVI — que o filho esperou encontrar, a narrativa rulfiana valoriza à oralidade sobre o escrito, como o descaso de Pedro Páramo (trecho 1) e a ironia de Toribio Aldrete (trecho 2) em conversa com Fulgor Sedano demonstram:

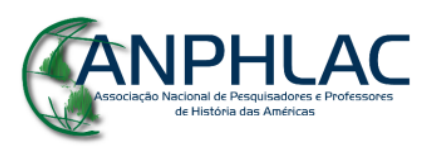

Revista Eletrônica da ANPHLAC, ISSN 1679-1061, №. 25, p. 222-251, Jul./Dez., 2018.

http://revista.anphlac.org.br 
Trecho $1^{33}$

- ¿Y las leyes? [pergunta Fulgor Sedano a Pedro Páramo]

- ¿Cuáles leyes, Fulgor? La ley de ahora en adelante la vamos a hacer nosotros. ¿Tienes trabajando en la Media Luna a algún atravesado?

$[\ldots]$

Pues mándalos en comissíon con el Aldrete. Le lavantas un acta acusándolo de 'usufruto' o de lo que a ti se te ocurra (RULFO, p. 108).

Trecho 2

"Que conste mi acusación por usufruto."

- A usted ni quien li quite lo hombre, don Fulgor. Sé que usted las puede. Y no por el poder que tiene atrás, sino por usted mismo.

$[\ldots]$

- Con ese papel nos vamos a limpiar usted y yo, don Fulgor, porque no va a servir para otra cosa (RULFO, p. 102-103).

Essa demonstração de poder não se trata apenas de uma representação do caciquismo histórico mexicano e que durante a Revolução se tornou conflituoso e mais intenso, mas expõe também uma negação do caráter sacro da palavra escrita perante aquilo que se diz, de ambos os lados. Ainda assim, Fulgor pede que um advogado falsifique um documento de posse para apresentar ao real dono da terra, Aldrete. Esvaziase - e reforça signos de poder próprios do caciquismo - o poder da palavra escrita e, ao fim, um processo jurídico de posse. O qual nos remete ainda à conquista realizada, por meio da linguagem, pelas cartas de relación, as quais não só descreviam o que os navegantes esperavam ver, como também afirmavam a posse a partir da nomeação do lugar, como um batismo. O Novo Mundo, pois, surgiu de uma violência do e no campo linguístico. Embasados em um ritual que era sequer de conhecimento dos indígenas, os conquistadores impunham o domínio da Coroa. Ao final do conto Nos han dado la tierra, que será analisado também adiante, essa imposição de uma linguagem e forma de interação com o mundo se repete:

— Pedro, señor delegado, la tierra está desvalada, dura.

33 Apesar dos trechos aqui estarem em ordem cronológica, na obra isso não acontece. Lê-se primeiro o assassinato de Toribio, em seguida, a conversa de Sedano e a apresentação do documento forjado e, por fim, a conversa do encarregado e a ordem de Pedro Páramo para falsificar um documento de posse por "usufruto".

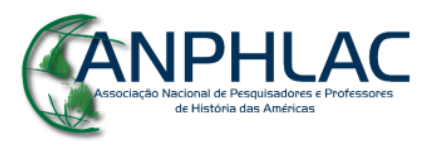

Revista Eletrônica da ANPHLAC, ISSN 1679-1061, №. 25, p. 222-251, Jul./Dez., 2018.

http://revista.anphlac.org.br 
$[\ldots]$

— Eso manifiéstenlo por escrito. Y ahora váyanse. Es al latifúndio al que tiene que atacar, no al Gobierno que les da la tierra.

Pero él no nos quiso oír (RULFO, 2004, p. 40).

A narrativa rulfiana continuamente expõe essa tensão entre o falar/ouvir e o ler/escrever. Ao nosso ver não se trata da demarcação dicotômica entre campo e cidade típica do realismo-naturalista, mas o desnudamento desse poder e dessa violência que se iniciam no campo da linguagem. Portanto, Rulfo realiza a negação de um mito fundador, por exemplo, na fala de Toribio para, em seguida, recriá-lo na arbitrariedade de Pedro Páramo. Juan Preciado, por sua vez, não encontra uma terra repleta de riquezas, como no relato materno, mas um vazio tomado pela morte, situado em um não-tempo.

\section{Nos han dado la tierra (1945) e o México revolucionário}

A narrativa rulfiana traz o descaso, mas é o peso da violência bruta e banal que lateja em suas entrelinhas. A derrocada da Revolução Mexicana para o campo em 1940 - após o ataque sofrido nas últimas décadas do século XIX —, e que ficaria cada vez mais clara ao longo da década, encerrava esse cenário ou, talvez, iniciava um luto.

Porfírio Diaz, cujo governo é conhecido como porfiriato — devido a sua longa duração —, foi presidente mexicano de 1876 até 1911 (com um breve intervalo entre 1880 e 1884). Seu governo, de teor ditatorial e autoritário, fez parte da primeira onda liberal-conservadora do México. Naquele momento, as ideias de progresso e de modernização eram o principal mote. Houve uma expansão considerável das linhas férreas e telefônicas, da indústria e da extração mineradora e uma projeção em direção às transformações liberais das instituições. Todavia, testemunhou-se uma retração espantosa do uso comunal da terra, genericamente conhecido por ejidos (KOURÍ, 2015) ${ }^{34}$, em face à concentração de terras. Em 1821, $40 \%$ das terras cultiváveis no Centro e no Sul pertenciam aos pueblos; em 1910, restavam apenas 5\% (BARBOSA, 2010). O salário real de um trabalhador, inclusive, em 1910 equivalia a uma curta parte do que era em 1800 (CARBONELL, 2002, p. 18; CAMIN \& MEYER, 2000, p. 13-16).

34 Em seu artigo, Emílio Kourí explica como o sistema legal mexicano, a partir de 1917, resumiu as várias formas de uso comunal da terra sob o termo ejido, que diz respeito apenas a um uso específico.

\section{CANPHLAC}

Revista Eletrônica da ANPHLAC, ISSN 1679-1061, №. 25, p. 222-251, Jul./Dez., 2018.

http://revista.anphlac.org.br 
Como qualquer outro processo modernizador — salvo as devidas diferenças — que ocorrera na América Latina, também o do México atendera apenas aos interesses políticos e econômicos de alguns poucos. Ao longo dos quase 35 anos do governo de Díaz, as tensões aumentaram até o momento em que a Revolução Mexicana eclodira. Essa é uma das dimensões incontornáveis da obra de Rulfo.

Se levarmos em conta o recorte temporal da narrativa de Pedro Páramo entre 1865 e 1927, a trama é coetânea ao processo de modernização e ataque à propriedade comunal encabeçadas pelos governos liberais mexicanos, como acima referido. Uma das recordações relatadas na obra é a de Fulgor Sedano, capataz e braço direito da família Páramo. É Fulgor quem põe em ação o plano de enriquecimento e domínio do patrão. Este não só arquitetou a tomada das terras das Preciado (Dolores Preciado) por via do casamento, como forjou documentação de posse sobre as terras de Toribio Aldrete além das terras dos Fregosos e Guzmanes. Após o desacordo daquele sobre a validade do documento falso, Sedano providenciou seu assassinato. Outra propriedade era a Enmedio, cuja tomada termina com o processo de concentração de terra que formará a Media Luna e o poder de Pedro Páramo ${ }^{35}$.

A Revolução surgiu, então, como resultado das décadas de usurpação das terras comunais em nome da industrialização e modernização do país, como ansiavam as elites políticas. Somou-se a isso o poder concedido a uma oligarquia, que entrara em choque com novos grupos ansiosos pelo poder. É entre 1910 e 1927 que a derrocada do cacique de Comala se inicia, inclusive. De acordo com Boixo, é por volta de 1910 que Miguel Páramo, filho de Pedro Páramo, morre ao cair de seu cavalo. Em 1911, seria a morte de Fulgor Sedano, o braço direito. Em 1914, a morte de Susana san Juan, paixão do cacique e, por fim, 1927, a morte de Pedro Páramo.

Nos anos seguintes a 1910, o México enfrentara um número extraordinário de conflitos armados entre diversos grupos, liberais, conservadores e setores da população, organizados ou não. Em seu seio ainda observou-se surgir o Exército Revolucionário do Sul, sob liderança de Emiliano Zapata, e o Exército Revolucionário do Norte, sob liderança de Francisco Villa, conhecido como Pancho Villa.

35 Fragmento nas páginas 103 e a 105.

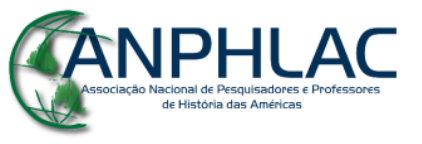

Revista Eletrônica da ANPHLAC, ISSN 1679-1061, №. 25, p. 222-251, Jul./Dez., 2018.

http://revista.anphlac.org.br 
Passada a fase mais violenta da Revolução, aprovada a Constituição de 1917 de caráter liberal e de razoável estabilidade política conquistada, Lázaro Cárdenas foi eleito em 1934 pelo Partido Nacional Revolucionario (PNR). Fora o último governo encabeçado por um caudillo e o primeiro de fato institucionalizado (SEMO, 1993, p. 197198). Cárdenas ficou conhecido por romper com o callismo (CARBONELL, 2002, p. 32$36)^{36}$, o qual tivera seus interesses isolados da população, dominada pelo caciquismo e caudillismo (SEMO, p. 1993, p. 214; CARBONELL, 2002, p. 45). Dessa forma, permitiu que as massas projetassem seus representantes em direção ao cenário público a partir de sindicatos e organizações sociais. O governo, apoiado por vários núcleos camponeses, fomentaria e desenvolveria um plano de reforma agrária cujo objetivo era reestruturar e modernizar o então chamado ejido. A partir de 1935, a reforma agrária andou a passos largos. Ao fim do governo Cárdenas, o ejido representava quase metade da superfície do México.

Por outro lado, o conto Nos han dado la tierra (1945), cinco anos distante do fim do governo cardenista, tecia críticas aos problemas enfrentados nos dois anos finais do governo cardenista e nos resultados efêmeros ou malfadados sofridos pelos camponeses mexicanos nos anos seguintes. Mimetiza à sua maneira o êxodo rural e a situação de abandono que os pueblos arcaram durante e após a Revolução Mexicana ${ }^{37}$.

No conto, um grupo de camponeses atravessa a pé uma enorme extensão de terra — "Hemos venido caminando desde el amanecer. Ahorita son algo así como las cuatro de la tarde" (RULFO, 2004, p. 37) — em direção ao pueblo mais próximo com o

36 O callismo é definido pela política empregada pelo general e presidente mexicano Plutarco Elias Calles (1924-1928) cuja fundamental estratégia foi estabelecer, dos bastidores, um pacto entre os diversos caudillos e elites políticas dos estados mexicanos sob a égide do Partido Nacional Revolucionário (PNR) —nomeado em 1938 no governo de Cárdenas, Partido de la Revolución Mexicana (PRM) e, por fim, em 1946, Partido Revolucionario Institucional (PRI) durante o governo de Manuel Ávila Camacho - no governo a partir de 1929, já no governo de Emílio Portes Gil (1928-1930), trazendo equilíbrio para as forças políticas. O PNR foi o centro das negociações de interesses entre os diversos grupos revolucionários protagonistas da Revolução Mexicana junto ao Executivo, o qual detinha enorme poder sobre as instituições e a política mexicana e era representado pela figura do então chamado "jefe máximo", o próprio Calles.

37 A emigração mexicana ainda hoje é uma realidade impactante. Com a segunda maior população de emigrantes do mundo, em 2017, apenas nos EUA viviam cerca de 13 milhões de mexicanos. Número que aumentou após as últimas eleições estadunidenses. Disponível em: $\langle$ https://datosmacro.expansion.com/demografia/migracion/emigracion/mexico> acesso em: 25 de outubro de 2018.

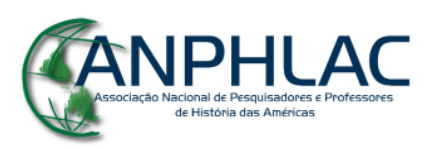

Revista Eletrônica da ANPHLAC, ISSN 1679-1061, №. 25, p. 222-251, Jul./Dez., 2018.

http://revista.anphlac.org.br 
objetivo de fazer reclame às autoridades acerca da qualidade de cultivo da terra que lhes fora dada. A terra infértil, em um lugar seco e distante da água, impedia o plantio e a subsistência de tais camponeses. O narrador, também na primeira pessoa do singular, conta aos poucos como o grupo de camponeses vai aos poucos minguando:

Somos cuatro. Yo los cuento: dos adelante, otros dos atrás. Miro más atrás y no veo a nadie. Entonces me digo: "Somos cuatro". Hace rato, como a eso de las once, éramos veintitantos; pero puñito a puñito se han ido desperdigando hasta quedar nada más este nudo que somos nosotros (RULFO, op. cit., p. 37).

Esse fragmento intensifica a sensação de dispersão e isolamento, além de apontar para o enfraquecimento da mobilização dos camponeses após o período revolucionário. No decorrer da narrativa, pouco a pouco é enfatizada tal pulverização. Isso fica claro quando o sujeito da narrativa reclama do desarmamento que sofreram - o que aliás é dito com tom de espanto, se levarmos em conta que o llano ainda se encontra morno pelo calor da Revolução - e da perda de suas montarias:

Y por aqui vamos nosotros. Los cuatro a pie. Antes andábamos a caballo y traíamos terciada una carabina. Ahora no traemos ni siqueira la carabina (RULFO, op. cit., p. 38).

Em sua análise sobre o cadernismo, Ilán Semo (1993) expõe as causas e as escolhas de Lázaro Cárdenas que levaram, desde 1938, a reforma social ao estancamento, tema central do conto. A política de cooptação dos diversos grupos, apesar do desmantelamento do caudillismo, fez com que os caciques se situassem no interior do Estado. O caciquismo, desde então, se transformou no seio das instituições e criou obstáculos à continuação das reformas sociais do governo. Visto que o modus operandi de tal grupo, composto por grandes ou médios proprietários de terras - estamos falando aqui justamente da personagem Pedro Páramo —, era íntimo do personalismo e do clientelismo $^{38}$. Dessa maneira, a estratégia de Cárdenas foi dar seguimento à reforma política e, sobretudo, à institucionalização da presidência, quando possibilitou a eleição de um novo governo junto do PRM. Caso contrário, temia-se que a política corresse risco

38 Entendemos por relações clientelares a troca desigual que subentende uma fidelidade entre as partes, seja política, econômica ou social (GRAHAM, 1990).

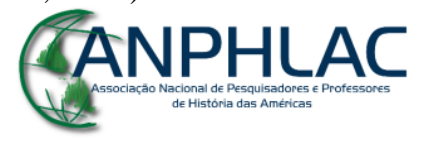

Revista Eletrônica da ANPHLAC, ISSN 1679-1061, №. 25, p. 222-251, Jul./Dez., 2018.

http://revista.anphlac.org.br 
de ser tomada pelas armas - daí o desarmamento indicado pelo camponês que narra mais uma vez, ao fragilizar a centralização do governo no então Partido de la Revolución Mexicana (PRM).

Semo, ao citar Frank Tannenbaum, discorre sobre a audaciosa tentativa do cardenismo de projetar a tradição a partir da modernidade. Foram três os impulsos fundamentais para isso:

[...] a reivindicação das formas não individuais de propriedade, geridas por seus membros e reguladas por sistemas de financiamento controlado e distribuição; a produção de uma nova cultura política que inverteu a ordem liberal entre o público e o privado, entre o social e o civil, e uma transformação do sistema de representação de interesses no Estado e no governo (SEMO, op. cit., p, 215).

Após as reformas cardenistas, entretanto, o México saía em 1947 de um processo eleitoral que terminava com o governo de Manuel Ávila Camacho (1940-1946), responsável pelo fim do esplendor do cardenismo, e dava início ao mandato de Miguel Alemán Valdés (1946-1952). Este, político reconhecido por seu posicionamento a favor de um capitalismo liberal e moderno, aceleraria novo impulso à modernização mexicana, na qual as reformas do fim da década de 1930 esmoreceram e ocasionaram um abandono profundo do campo, levando a um crescimento urbano acelerado e desorganizado, seguido de favelização. Os camponeses de Nos han dado la tierra, por fim, seguiram "adelante, más adentro del Pueblo. La tierra que [ganharam ficou] allá arriba" (RULFO, 2004, p. 42).

\section{Conclusão}

Em carta a sua esposa, Clara Aparicio Reyes, datada de 1947, o Rulfo de trinta anos fazia reclames sobre seu emprego na indústria Goodrich, para a qual vendia pneus:

Eles [os operários] não podem ver o céu [...] Vivem enegrecidos durante oito horas, por dia ou por noite, constantemente, como se não existisse o sol nem nuvens no céu para que eles as vejam, nem ar limpo para que eles sintam. Sempre assim e incansavelmente, como se somente no dia de sua morte pensarão em descansar. [Mais a frente] Creio que não resistirei muito a ser essa espécie de capataz que querem

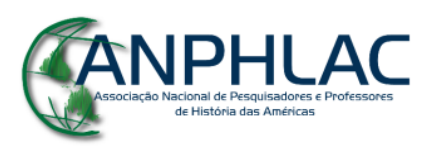

Revista Eletrônica da ANPHLAC, ISSN 1679-1061, №. 25, p. 222-251, Jul./Dez., 2018.

http://revista.anphlac.org.br 
que eu seja. E só o pensamento de trabalhar assim já me sinto triste e amargo (RULFO, 2017, p. 143).

Nesse trecho, vemos um Rulfo desgostoso pela maneira como os operários mexicanos trabalhavam na indústria, símbolo da modernização, devido à imposição de seu emprego em vigiá-los: "como se fosse pouca a vigilância das máquinas que os têm e que não conhecem a paz da respiração" (RULFO, op. cit., p. 143). Adiante na mesma carta, diz desejar mudar-se para uma casa que tivesse pássaros. Sentia-se enfermo com sua estadia na capital mexicana e a velocidade da cidade moderna: parafraseando o escritor, como se uma corrente de rio o arrastasse, como se o empurrassem, como se não o deixassem olhar para trás. Surpreendido pela força fabril dizia: "trata-se aqui um mundo estranho no qual o homem é uma máquina e a máquina é considerada um homem" (RULFO, op. cit., p. 144). Continua: "nunca ter visto tanta matéria junta; tanta força unida para acabar com o sentido humano do homem" (RULFO, op. cit., p. 146).

Juan Rulfo foi crítico ao modelo de modernização encabeçado pelo Partido Revolucionário Institucional (PRI), que estava no governo desde 1929, e aos próprios resultados da Revolução Mexicana. Nas décadas de 1940 e 1950, sua escrita não apenas valorizava a cultura popular mexicana, como ainda hoje é entendida, bem como inaugurava a memória de um pueblo imaginado perante os atropelos da modernização e dos projetos de governo do PRI, que faziam da Revolução Mexicana uma tópica de seu discurso e um suposto horizonte para o qual se caminhar.

Em 1979, ao ser indagado sobre a relação entre seu contato com a violência e a morte prematura de seu pai, Rulfo explicou de onde surgia e como se dava tal violência: "casi toda la tiera caliente del pays es violenta". Pouco mais adiante indicou quais os motivos para tanto: o isolamento de tais zonas: "la tierra caliente le da una característica a la persona (...) donde importa muy poco la vida"; e, por fim, o despovoamento e o êxodo rural, causados ora pela migração interna, em direção à costa ou ao "altiplano", ora externa, em direção aos Estados Unidos.

Tais apontamentos do escritor não se resumem a uma ideia dicotômica entre um campo, violento e arcaico, e uma cidade, moderna e civilizada. Essas palavras de Rulfo são sintomas compartilhados e produzidos ao longo de um processo que fez da política no México e a sociedade íntimas da violência. A Revolução e seu desenrolar não foram

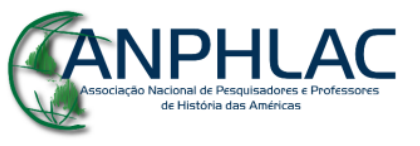

Revista Eletrônica da ANPHLAC, ISSN 1679-1061, №. 25, p. 222-251, Jul./Dez., 2018.

http://revista.anphlac.org.br 
diferentes disso: findara como mais uma esperança sufocada pelos poderes locais e pelas instituições tomadas pelo personalismo e por interesses patrimonialistas.

A narrativa rulfiana abandonou, portanto, a ideia de uma Revolução Mexicana ainda por se realizar e contradisse tal discurso ao nomear um passado a partir da morte de um pueblo. Em meados do século XX, Rulfo, bem como Octávio Paz, ainda que em termos divergentes, dava forma narrativa a uma memória da violência, enquanto encarava a questão sobre o que era, de fato, Jalisco nesses caminhos que direcionaram o México até ali e, em última instância, o que era o México. Segundo o escritor, "Jalisco é um Estado rodeado de México por todas as partes, menos pelo mar [...] Um litoral muito grande para tão poucos foragidos” (RULFO, 1964). Forçoso dizer que tal indagação latejava em toda a América Latina, principalmente com a proximidade dos centenários das independências.

Los recuerdos dos habitantes de Comala ainda hoje murmuram no México a memória das consequências do mandonismo, da ganância pela terra, da arbitrariedade e da ideia de que no pueblo não há um futuro. A escrita de Rufo nos diz que, sim, há um futuro para esse pueblo, um pueblo outro e que não está naquilo que as instituições dizem; mesmo que seja reinventado pela escrita, nem que seja do túmulo.

\section{REFERÊNCIAS BIBLIOGRÁFICAS}

ASSMANN, Aleida. Espaços da Recordação: formas e transformações da memória cultural. Campinas, SP: Editora UNICAMP, 2001.

BARBOSA, Carlos Alberto Sampaio. A Revolução Mexicana. São Paulo: Editora UNESP, 2010.

BARTHES, Rolland. O rumor da língua. São Paulo: Martins Fontes, 2004.

BOIXO, José Carlos Gonçález. La estética del ruralismo en los cuentos de Juan Rulfo. In: El cuento hispanoamericano del siglo XX. Teoría y práctica, Eva Valcarcel ed. A Coruña: Universidade, 1997, p. 201-212. Disponível em: < http://hdl.handle.net/2183/9728>. Acesso em: 23 jul. 2016.

BOSI, Alfredo. Literatura e resistência. São Paulo: Companhia das Letras, 2002.

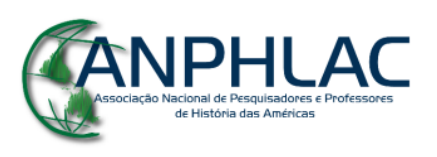


BUTLER, Matthew. Cristeros y agraristas en Jalisco: una nueva aportación a la historiografia cristera. Historia Mexicana, vol. LII, n. 2, oct-nov, 2002.

CAMIN, Héctor Aguilar; MEYER, Lorenzo. À sombra da Revolução Mexicana: história mexicana contemporânea, 1910-1989. São Paulo: EDUSP, 2000.

CANDIDO, Antônio. Literatura e sociedade. $9^{\mathrm{a}}$ ed. Rio de Janeiro: Ouro Sobre Azul, 2006.

CARBONELL, José. El fin de las certezas autoritárias: hacia la construccíon de um nuevo sistema político y constitucional para México. México: Universidad Nacional Autónoma de México, 2002.

CÓRDOVA, Arnaldo. La Revolución y el Estado en México. México: Editora Era, 1989.

DELEUZE, Gilles (2003) Proust e os signos. 2.ed. trad. Antonio Piquet e Roberto Machado. Rio de Janeiro: Forense Universitária, 2003.

DOVE, Patrick. Exígele lo nuestro: Deconstruction, Restitution and the Demand of Speech in Pedro Páramo. In: Journal of Latin American Cultural Studies, vol. 10, n. 1, 2001.

ECHEVARRÍA, Roberto González. Mito y archivo: una teoría de la narrativa latinoamericana. México: Fondo de Cultura Econômica, 2000.

GOMES, Warley Alves; ANDRADE, Carolline Martins. A literatura sob fogo cruzado: o "Romance da Revolução Mexicana" e a construção de uma "cultura revolucionária". In: Revista Eletrônica da ANPHLAC, n. 23, jul-dez de 2017, p. 56-81. Disponível em: <http://revistas.fflch.usp.br/anphlac/article/view/2866> Acesso em: jan. de 2018.

GREENBLATT, Stephen. Possessões maravilhosas: o deslumbramento do Novo Mundo. São Paulo: Editora da Universidade de São Paulo, 1996.

ISER, Wolfgang. Os atos de fingir ou o que é fictício no texto ficcional. In: LIMA, Luiz Costa. (Org). Teoria da literatura em suas fontes. vol. 2, $3^{\text {a }}$ ed. Rio de Janeiro: Civilização Brasileira, 2002.

KOURÍ, Emílio. La invención del ejido. Revista Nexos: $1^{\circ}$ de en. 2015. Disponível em: <http://www.nexos.com.mx/?p=23778> Acesso em: 24 de abril de 2017.

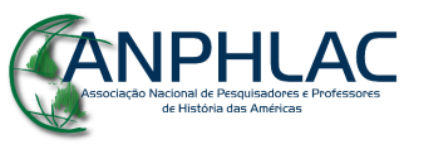

Revista Eletrônica da ANPHLAC, ISSN 1679-1061, №. 25, p. 222-251, Jul./Dez., 2018.

http://revista.anphlac.org.br 
LANDA, Mariano Báez. De indígenas a campesinos: miradas antropológicas de un quiebre paradigmático. In: Revista Ruris, vol. 3, n. 2, ago de 2009 a fev de 2010. Disponível em: < https://www.ifch.unicamp.br/ojs/index.php/ruris/article/viewFile/695/560> Acesso em mai. De 2018.

LEVINE, Suzanne Jill. "Pedro Páramo e Cien años de soledad: un paralelo" In: Revista de Universidad de México, v. XXV, n. 6, fev. 1971, p. 18-24.

MEYER, Jean. La Cristiada: la guerra de los cristeros. México: Siglo XXI Editores, 2004.

PAZ, Octavio. El labirinto de la soledad. $2^{\mathrm{a}}$ ed. México: Col. Popular, 1992.

PESAVENTO, Sandra. História \& Literatura: uma velha-nova história. In: Nuevo Mundo Mundos Nuevos (Online), Debates, 2006. Disponível em: 〈https://journals.openedition.org/nuevomundo/1560〉. Acesso em jul. de 2016.

RAMA, Ángel. AGUIAR, Flávio; GUARDINI, T. Vasconcelos (orgs.). Ángel Rama: literatura e cultura na América Latina. São Paulo: EDUSP, 2001.

RAMA, Ángel. Transculturación narrativa en América Latina. $2^{\mathrm{a}}$ ed. . Buenos Aires: Ediciones El Andariego, 2008. , Ángel. La ciudad letrada. Montevideo: Editora Arca, 1998.

SEMO, Ilán. El cardenismo revisado: la tercera vía y otras utopias inciertas. Revista mexicana de sociología, vol. 55, no. 2, 1993.

SILVA, Caio Pedrosa da. "Soldados de Cristo Rey": representações da Cristera entre a historiografia e a literatura (México, 1930-2000). UNICAMP: Dissertação de Mestrado, julho de 2009.

VITAL, Alberto. Notícias sobre Juan Rulfo: la biografía, 1762-2016. Ciudad de México: Editorial RM, 2017.

TAPIA, Maura. Entrevista realizada por Yanet Aguillar Sosa e conferida pela subdiretora de acervos da Comisión Nacional para el Desarollo de los Pueblos Indígenas (CDI), publicada em 15 de mai. de 2017 pelo jornal El universal. Disponível em: <

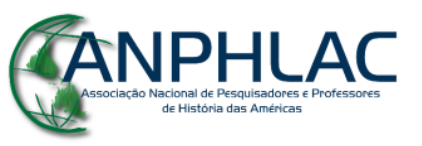

Revista Eletrônica da ANPHLAC, ISSN 1679-1061, №. 25, p. 222-251, Jul./Dez., 2018.

http://revista.anphlac.org.br 
http://www.eluniversal.com.mx/articulo/cultura/letras/2017/05/15/juan-rulfo-la-historiadel-editor-indigenista\#timagen-1> Acesso: 26 fev. de 2018.

\section{REFERÊNCIAS DOCUMENTAIS}

RULFO, Juan. El llano en llamas. Carlos Blanco Aguinada (ed.). $15^{\mathrm{a}}$ ed. Madrid: Ediciones Cátedra, 2004.

Juan. Pedro Páramo. 27. ed. José Carlos González Boixo (ed.). Madri: Ediciones Cátedra, 2015.

, Juan. Entrevista concedida em 1977 ao programa televisivo espanhol A fondo. Disponível em: < https://www.youtube.com/watch?v=V74yJztkx-c>. Acesso em: $18 \mathrm{de}$ jun. de 2016.

, Juan. Entrevista publicada originalmente em Siempre! La cultura en México, núm. 1,051 (15-VIII-1973), pp. VI-VII. (Juan Rulfo respondeu por escrito a esta entrevista).

, Juan. Entrevista concedida a Miguel Briante. Rulfo: el silencio interrumpido. In: Revista Confirmado. Argentina, Buenos Aires, año IV, 1968. Disponível em: $<$ http://ccpe.org.ar/rulfo-el-silencio-interrumpido-miguel-briante> Acessado em: $10 \mathrm{de}$ ago. 2016.

, Juan. Entrevista concedida a Juan Cruz. Juan Rulfo: "no puedo escribir sobre lo que veo". In: Revista Actualidad. España: El país, 19 de agosto de 1979. Disponível em: $<$ http://elpais.com/elpais/2015/07/27/actualidad/1437991191_012418.html> Acesso em: 10 de ago. de 2016.

, Juan. La tierra pródiga In Revista Mexicana de Cultura, suplemento de El Nacional, $\mathrm{n}^{\circ}$ 919, 8 de nov. de 1964. Disponível em:

<https://www.letraslibres.com/vuelta/la-tierra-prodiga > Acesso em: 14 de nov. de 2018.

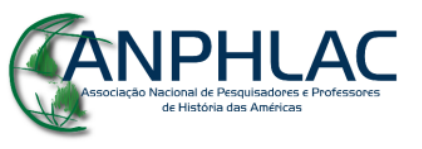

Revista Eletrônica da ANPHLAC, ISSN 1679-1061, №. 25, p. 222-251, Jul./Dez., 2018.

http://revista.anphlac.org.br 